\title{
Correction: Resolution of apparent paradoxes in the race-specific frequency of use-of-force by police
}

\section{Cody T. Ross ${ }^{1}$, Bruce Winterhalder ${ }^{2} \&$ Richard McElreath ${ }^{1}$}

Correction to: Palgrave Communications https://doi.org/10.1057/s41599-018-0110-z, Published online 5 June 2018.

The sub-section 2.1 of the Supplementary Information file in the original article was incorrect. This whole sub-section has now been removed.

This article has been corrected online.

Published online: 28 August 2018

(c) Open Access This article is licensed under a Creative Commons Attribution 4.0 International License, which permits use, sharing, adaptation, distribution and reproduction in any medium or format, as long as you give appropriate credit to the original author(s) and the source, provide a link to the Creative Commons license, and indicate if changes were made. The images or other third party material in this article are included in the article's Creative Commons license, unless indicated otherwise in a credit line to the material. If material is not included in the article's Creative Commons license and your intended use is not permitted by statutory regulation or exceeds the permitted use, you will need to obtain permission directly from the copyright holder. To view a copy of this license, visit http://creativecommons.org/licenses/by/4.0/.

(C) The Author(s) 2018

\footnotetext{
${ }^{1}$ Department of Human Behavior, Ecology and Culture. Max Planck Institute for Evolutionary Anthropology, Leipzig, Germany. ${ }^{2}$ Department of Anthropology, University of California, Davis, USA. Correspondence and requests for materials should be addressed to C.T.R. (email: cody_ross@eva.mpg.de)
} 